\title{
No More Black Fridays
}

\author{
WENDY HARCOURT
}

I write this editorial as the 16th Conference of Parties (COP) closes in the beach resort town of Cancun, Mexico in another attempt at climate negotiations. Even before the outcome was known the Conference had been mired by media cynicism and reports of diplomatic failure. There is little expectation that these climate negotiations will usher in real global cooperation, burden sharing and accountability.

Following the failure of the 15th COP held in Copenhagen, December 2009 there seems to be a consistent inability for governments to find ways to move forward that bodes ill for the end of the Kyoto Protocol in 2012. Some of the squabbles are about finance. It is unclear if the US\$30 billion pledged in Copenhagen to support mitigation and adaptation in the South will materialize. The recommendation of the High-level Advisory Group on Climate Change Financing is that US\$100 billion must be found annually for climate actions in developing countries. ${ }^{1}$ We can add that dream to the rest of the long climate wish list: science-based targets, a democratically governed global climate fund, a funded adaptation framework, technology and investment cooperation and a strategy for tackling intellectual property rights and trade disputes, as well as a pro poor forestry and land use agreement, national low and zero emission reduction targets (Athanasiou, 2010).

Some are hopeful that Cancun will lead to financial transparency of the North. Others have just given up. The Economist (2010) states upfront that 'global action is not going to stop climate change. The world needs to look harder at how to live with it'. Its four-page Briefing elaborates why we need to adjust to difficult years ahead, where poor people will 'adapt' by mass migration and the rich people will learn to survive the unpredictable weather patterns. It uncritically comments that one group of Oxford development economists suggests that instead of aid to African farmers it would be much better if the farmers were encouraged to move to cities. From a comfortable Eurocentric standpoint, The Economist reassures us that at least in this century the Dutch will do fine, though not the Pacific Islanders. The stark message is that those countries with money and know-how will win out.

Sadly though, most of the world is just not registering the importance of Cancun. Take mainstream media on the weekend before it began (27 and 28 November 2010) where climate was hardly mentioned. The headline stealer was Black Friday: the Friday after US Thanksgiving when US shopkeepers are meant to go in the black. Markets 
and newspapers in the US and across the world reported with relief that retail sales on Black Friday rose by 15.9 percent, with around-the clock-sales and hordes of frenzied shoppers making savvy choices. There was an increase of 4 percent from last year's Black Friday. Online shopping boomed. All bodes well for economic 'recovery' for the US, and therefore the global economy. ${ }^{2}$

Massive US shopping sprees are not going to get us out of the crisis; indeed, such consumer behaviour can only worsen and deepen it. The invisibility of and cynicism around Cancun and the pages of analysis and interest in Black Friday are both symptoms and causes of the multiple crises we all find ourselves in. The articles in this issue on Global Land Grabs put us back in the picture.

The articles show how in rural areas throughout Latin America, Africa and Asia communities and their livelihoods are being crushingly pushed aside in deals that are forcing large-scale migration, violent conflicts, unemployment, deepening poverty and hunger.

Though the lives of small farmers seem removed from the bargain tables of WalMart the journal's message is that they are closely linked. The modern life of fuel-guzzling cars, huge shopping malls, air-conditioned/central-heated living, middle-class enclaves in the Global South and sprawling suburbs of middle America and equivalents in other rich countries are relentlessly destroying biodiversity, the land and water ways of the rural livelihood and the commons. While the world's middle classes enjoy out-of-season luxuries from giant supermarkets, choices of bottled water, discard last year's unfashionable jeans and plan their holidays abroad, the majority of the world struggle to find jobs, clean water and ways to keep their families together and have enough calories to survive.

The articles reveal what it means to be one of the 50 million 'climate' refugees: how it feels to have your heritage and culture gutted, be left jobless and your family fractured. The articles are no less pertinent for being depressingly familiar. Even if the times have changed, the 'violence of development' is still evident, with land grabs engineered by governments and outsiders in the name of modernity, resulting in further poverty old, even if in the twenty-first century the OECD countries are joined by China and Brazil, they all cut deals at World Bank and IMF meetings and the real winners are the multinational corporations who cruise in at the invitation of everyone but the people who will lose their livelihoods.

Unlike The Economist the authors are not giving up. The articles underline that the answer cannot be left up to climate negotiators, nor to 'greening' development projects. It would help if the middle classes throughout the globe could start by saying, we have enough, no more Black Fridays. Do I really need an iPad, a new computer, more jewelry, more brand-name clothes? It would help if people living in Amsterdam, Rome and Madrid make the connection between the young men deserting their villages in West Africa to sell unwanted bric-a-brac on the streets and the current food crises and climate crises (Bunting, 2010). They leave because they have no jobs, no lands and no future. As Camilla Toulmin (2009) states in her book on climate change in Africa, the continent's ecosystems and peoples are under threat. Climate change is part and parcel of the same economic system that fails to deliver on aid promises, as it is now failing to deliver on climate promises.

Mind you the system is cracking a little. As several articles in this issue point out even the World Bank, that doyen of neo-liberalism, has begun to question whether foreign land investments for cash crops such as agrofuels are actually benefiting the local people (World Bank, 2010). Well, that is what the leaked draft report stated, the final release was less clear (see Book Reviews in this issue). There are several attempts by UN agencies to set up frameworks and protocols to lessen the damage, as the Land Research Action Network (LRAN) spells out in its introductory article.

The inequality of the global land grabs seems somehow chillingly worse given all the discussion on food, climate and care crises. What hope can we have given these circumstances?

One of the answers is first knowing about it, and acknowledging it as an issue wherever we live, with full awareness of today's global connections and crises. Second, using governance mechanisms that are there in order to push global 
accountability, and making good the promises and vision of climate justice. And third, understanding and supporting the activities of communities who are directly on the front line.

This means thinking beyond aid and charity solutions, beyond disaster scenarios and climate denial and beyond the current North-South impasse to talk about the commons we are sharing. Citizens living in elite urban enclaves in the North and South need to change ways of life and values in order to stop the selling of land, forests, water and land, the destruction of communities, traditions and knowledge.

Laura Carlsen (2010) put it starkly in her recent post on 'Foreign Policy in Focus', there are two worlds that were colliding at the Cancun climate talks. Joining leaders from the political and business world were members of peasant and farmers organizations, indigenous peoples and social movements (including members of LRAN who have contributed to this issue). They came with their own plans for socially and environmentally sustainable solutions to climate change. Instead of market-based mechanisms and technological fixes, these groups proposed alternatives to "profits before people and nature. ${ }^{3}$

These organizations brought the message of 'thousands of people's solutions to climate change'. They spoke about forests, biodiversity and clean water, not carbon sinks and greening projects. Their demand was that governments address the current development model of production, trade and consumption that has caused the financial, food, climate and care crises. They spoke about the role of women and the gendered aspects of climate change, something not well understood as Jessica Chu points out in this issue of Development, and the need for the "territorial and cultural rights of indigenous and peasant peoples to be explicitly recognized in any climate accord. ${ }^{4}$

Their main medium was the social media in Cancun in order to keep the pressure on negotiators, and world awareness of the events with onthe-ground reporting of activities through radio streams, blogs, podcasts and daily Web updates. Websites such as tcktcktck.org and earth350.org offered graphic illustrations of how people are creatively trying to keep the focus on what climate change means for all of us.

This issue is the first of Volume 54 on 'Sustainability'. It opens with the graphic unsustainability of global land grabs. The second issue, to be launched at the SID World Congress in July 2011 in Washington, publishes opinions from young and old leaders, researchers, development policymakers, social movements and ecologists on what they see as further challenges to sustainability. A third issue looks at sustainable cities to assess realities of urban development and the fourth explores in detail cosmovisions, the alternative visions to current Eurocentric development models.

None of the issues in this volume will make for easy reading, but we can take courage from those who look for solutions that can work. As author Shalmali Guttal told me, 'The situation is actually depressing and grim ... I take heart from working with groups who are engaged in struggles to reclaim their territories and build collectives for different models of living, eating, producing. ${ }^{5}$

\section{Notes}

1 http://www.un.org/News/Press/docs/2010/sgsm13232.doc.htm.

2 http://latimesblogs.latimes.com/money_co/2010/11/retail-roundup-black-friday-edition.html.

3 See the Caravans-Global Exchange, http://www.globalexchange.org/war_peace_democracy/climatechange/COP16/ CancunCaravan.html.

4 Both quotes in this paragraph come from La Via Campesina: http://www.viacampesina.org the statements can be read in full at http://www.redd-monitor.org/2010/09/02/via-campesina-rejects-redd-and-carbon-trading/.

5 Private correspondence, 23 November 2010.

\section{References}

Athanasiou, Tom (2010) 'The Cancun Setup One Year after Copenhagen and Counting', http://www.ecoequity.org, accessed 16 November 2010 (http://www.ecoequity.org/2010/11/the-cancun-setup-one-year-after-copenhagenand-counting/\#more-910). 


\section{Development 54(1): Editorial}

Bunting, Madeleine (2010) 'The Giddens Paradox: Understanding climate change too late', in Comment and Debate, The Guardian Weekly, 5 November: 19.

Carlsen, Lauren (2010) 'Worlds Collide at Cancun Climate Talks', Foreign Policy in Focus, 27 October, http://www .fpif.org/articles/worlds_collide_at_cancun_climate_talks.

The Economist (2010) 'Facing the Consequences', Briefing Adapting to Climate Change, 27 November 2010: 79-83.

Toulmin, Camilla (2009) Climate Change in Africa, London: Zed Books.

World Bank (2010) Rising Global Interests in Farmlands: Can it yield sustainable and equitable benefits? Washington: World Bank. 